\title{
Contribution to the knowledge of the Lepidoptera Fauna of the lower Sangro valley in the Abruzzo region of Central Italy
}

\author{
N. Zahm \\ Entomologist
}

\begin{abstract}
We report the results of recording Lepidoptera in the lower Sangro valley during a period of 22 years. The investigations were devoted to Macroheterocera and were carried out in the two regional nature reserves Oasi di Serranella and Lecceta di Torino di Sangro. The listing also includes some Microlepidoptera as non-target species, as well as occasionally observed butterflies. The 401 recorded species are presented in a table indicating both the locality of the records and the observed flight times and periods of activity. Fifteen species are published for the Abruzzo region for the first time; 2 species are new for the Italian peninsula.
\end{abstract}

\section{Introduction}

We investigated the fauna of the lower Sangro valley from 1988, with a particular focus on Macroheterocera. We also aimed to verify occurrence and distribution of the Lepidoptera of Central Italy. The butter-

Correspondence: Norbert Zahm, Ludwig-Uhland-Str. 34, D-66839 Schmelz, Germany. Tel. +49.6887.4357. E-mail: nzahm@t-online.de

Key words: lower Sangro valley, Macroheterocera.

Acknowledgments: the author would like to thank Dr. A. Natale and M. Pellegrini for their permission to carry out the research and their active support with its realization. Hi would also like to thank Dr. E. Priesner ( $\dagger)$, who supplied the pheromones. Thanks go to A. Werno for the determination of some Microlepidoptera, to Dr. H. Schreiber for the English translation and S. and C. Gaia and H. Gay for the carful proofreading, and to R. Hinsberger, E. Müller and M. Pellegrini for the photographs.

Received for publication: 26 April 2012.

Revision received: 14 November 2012.

Accepted for publication: 14 November 2012.

CCopyright N. Zahm, 2012

Licensee PAGEPress, Italy

Journal of Entomological and Acarological Research 2012; 44:e14

doi:10.4081/jear.2012.e14

This article is distributed under the terms of the Creative Commons Attribution Noncommercial License (by-nc 3.0) which permits any noncommercial use, distribution, and reproduction in any medium, provided the original author(s) and source are credited. flies observed and the few Microlepidoptera, collected together with the Macroheterocera are also listed.

\section{Materials and methods}

The study was carried out in two regional protected areas: the Oasi di Serranella $\left(42^{\circ} 07^{\prime} 35^{\prime \prime} \mathrm{N}, 14^{\circ} 22^{\prime} 40^{\prime \prime} \mathrm{E}\right)$ and the Lecceta di Torino di Sangro ( $\left.42^{\circ} 13^{\prime} 50^{\prime \prime} \mathrm{N}, 14^{\circ} 32^{\prime} 20^{\prime \prime} \mathrm{E}\right)$. In addition, light catches were carried out twice (July $13^{\text {th }}$ and $15^{\text {th }} 2000$ ) on the beach of the Sangro valley ( $42^{\circ} 14^{\prime} 31^{\prime \prime} \mathrm{N}, 14^{\circ} 31^{\prime} 30^{\prime \prime} \mathrm{E}$, at sea level), but with little success.

The Oasi di Serranella was investigated at irregular intervals a total of 49 times from 1988 to 2010. The main focus was on observations at night. Rhopalocera were registered only during occasional walks in the protected area. Pheromones, provided by E. Priesner, were used once on June $21^{\text {st }} 1991$ to look for Sesiidae.

The Lecceta di Torino di Sangro was intensively studied with respect to night active Macrolepidoptera for two years (2006-2007), excluding the slope towards the sea. Different investigation times were fixed to facilitate observation of the broadest possible spectrum of species. In 2006 , investigations were carried out during the periods from May $16^{\text {th }}$ to June $16^{\text {th }}$ and from September $12^{\text {th }}$ to October $12^{\text {th }}$. In 2007 , they were carried out from July $20^{\text {th }}$ to August $3^{\text {rd }}$. In total, there were 26 night catches. Occasionally, during daytime selection of light catching sites, some species of butterfly were observed and registered.

Active observation was necessary due to the lighting methods employed. These consisted of a gaze tower with a 250 watt compound light bulb and a black light tube connected to a super actinic tube. A generator served as energy source.

Easily recognizable species were recorded at the illuminated site and samples were collected. Species not determinable with certainty were also sampled. Recordings have been archived in the collection of the author.

Some of the Microlepidoptera were given to A. Werno, who compiled a list of identified species that has been integrated into the list of results (Table 1) and marked in the column footnotes.

The collected specimens were determined by the author. Identification literature (e.g., Fibiger, 1990-2010; Hausmann, 2001, 2004; Mironov, 2003; Weigt, 2009) and comparable collections were consulted where necessary. Dissection was performed on species that were difficult to identify and individual specimens that were anomalous.

All recorded data are stored in an Oracle databank. Specific individual data on certain species are available from the author on request. Informations about the distribution of the species have been found in the literatures (Prola et al., 1978a, 1978b; Prola \& Racheli, 1979, 1980; Teobaldelli, 1976; Sciarretta \& Zahm, 2002; Parenzan \& Porcelli 20052006, 2006-2007). 


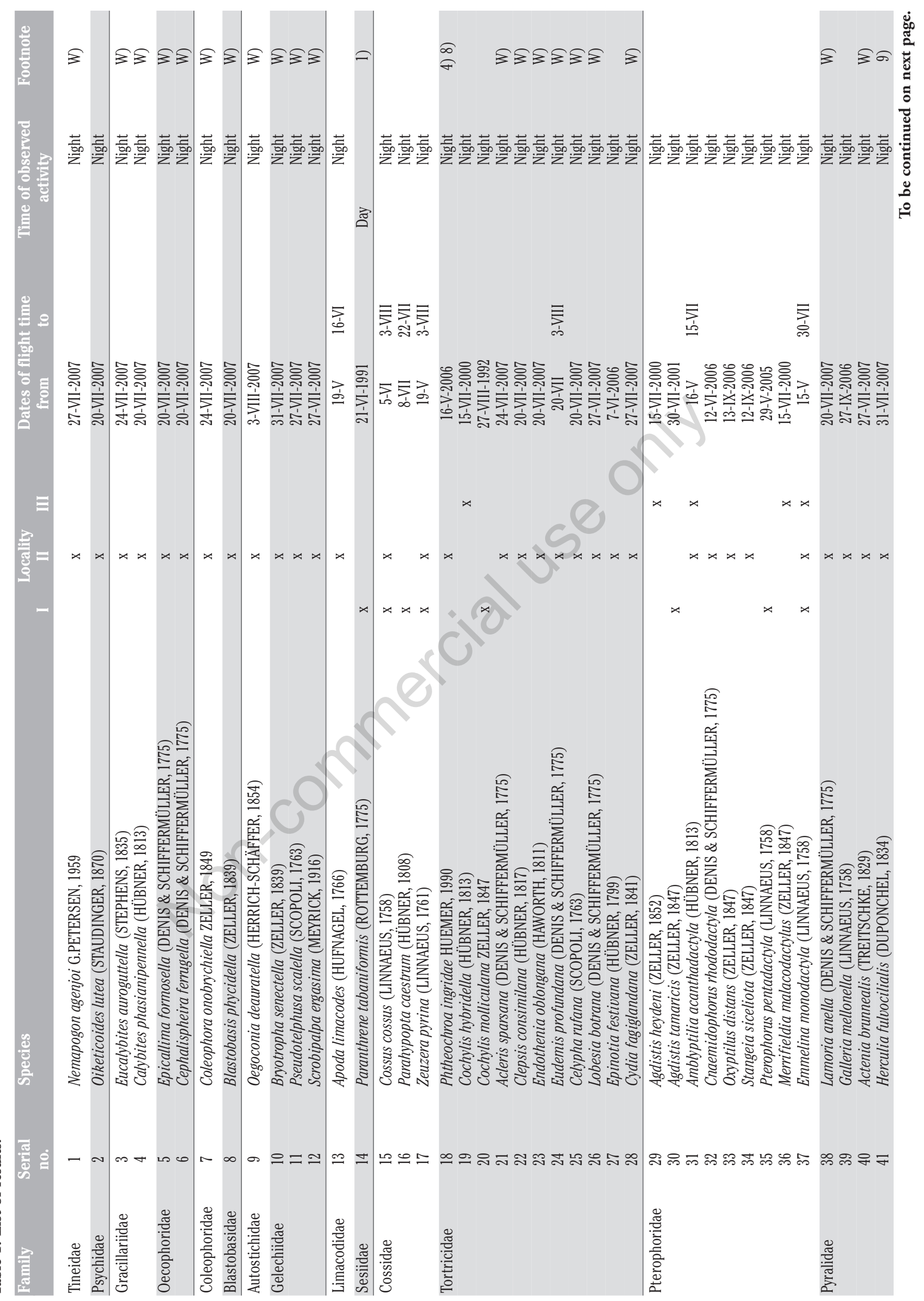




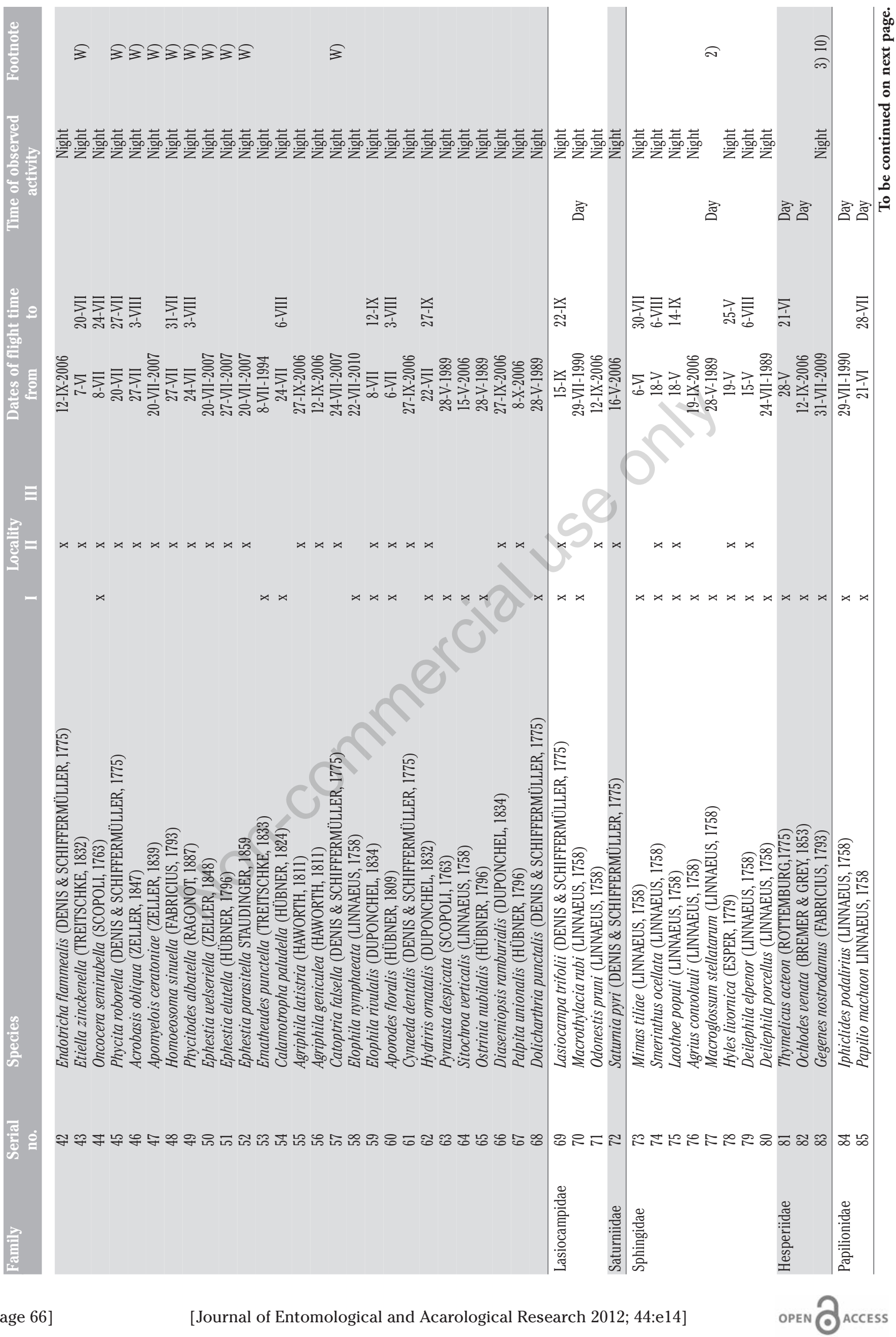




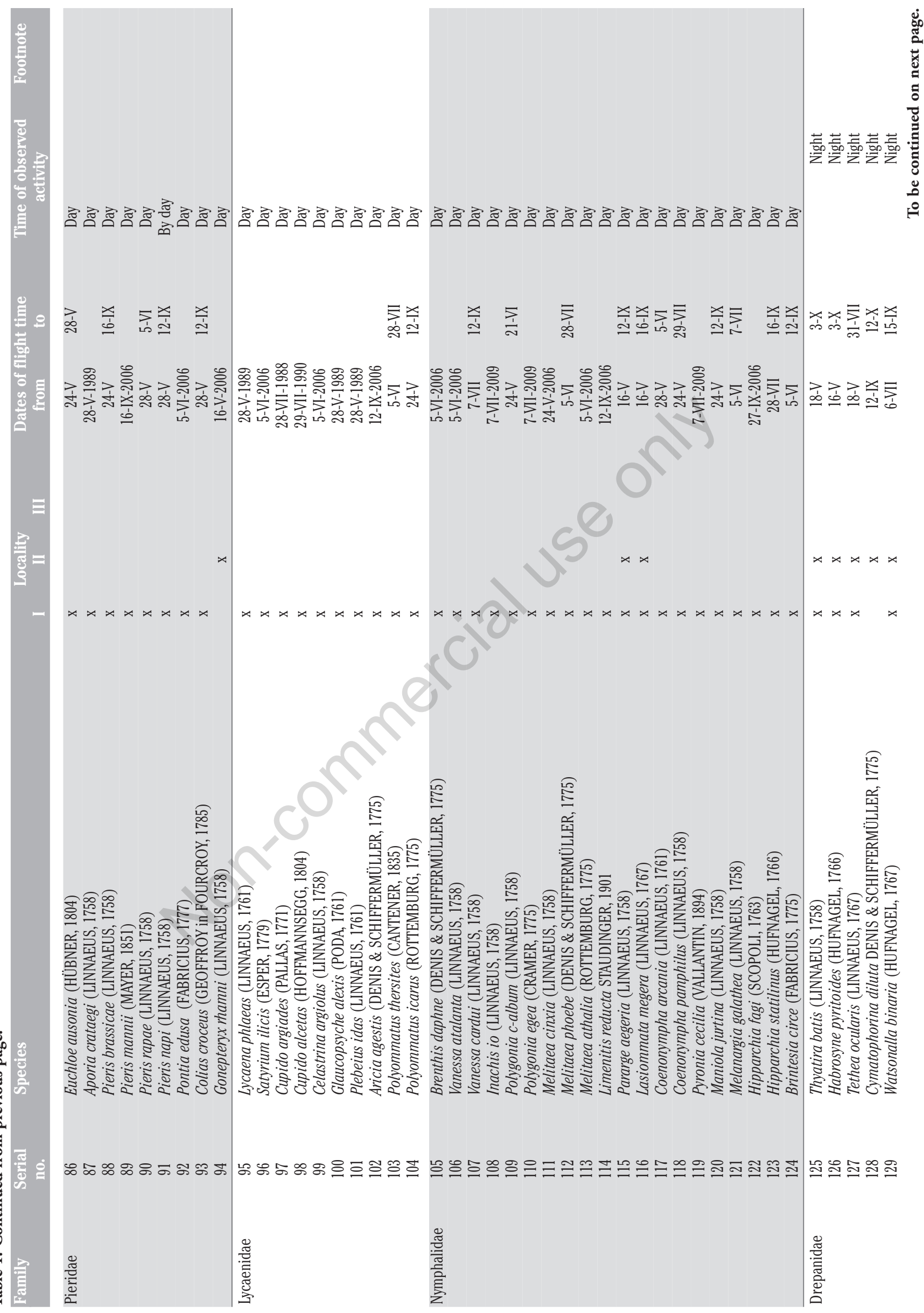




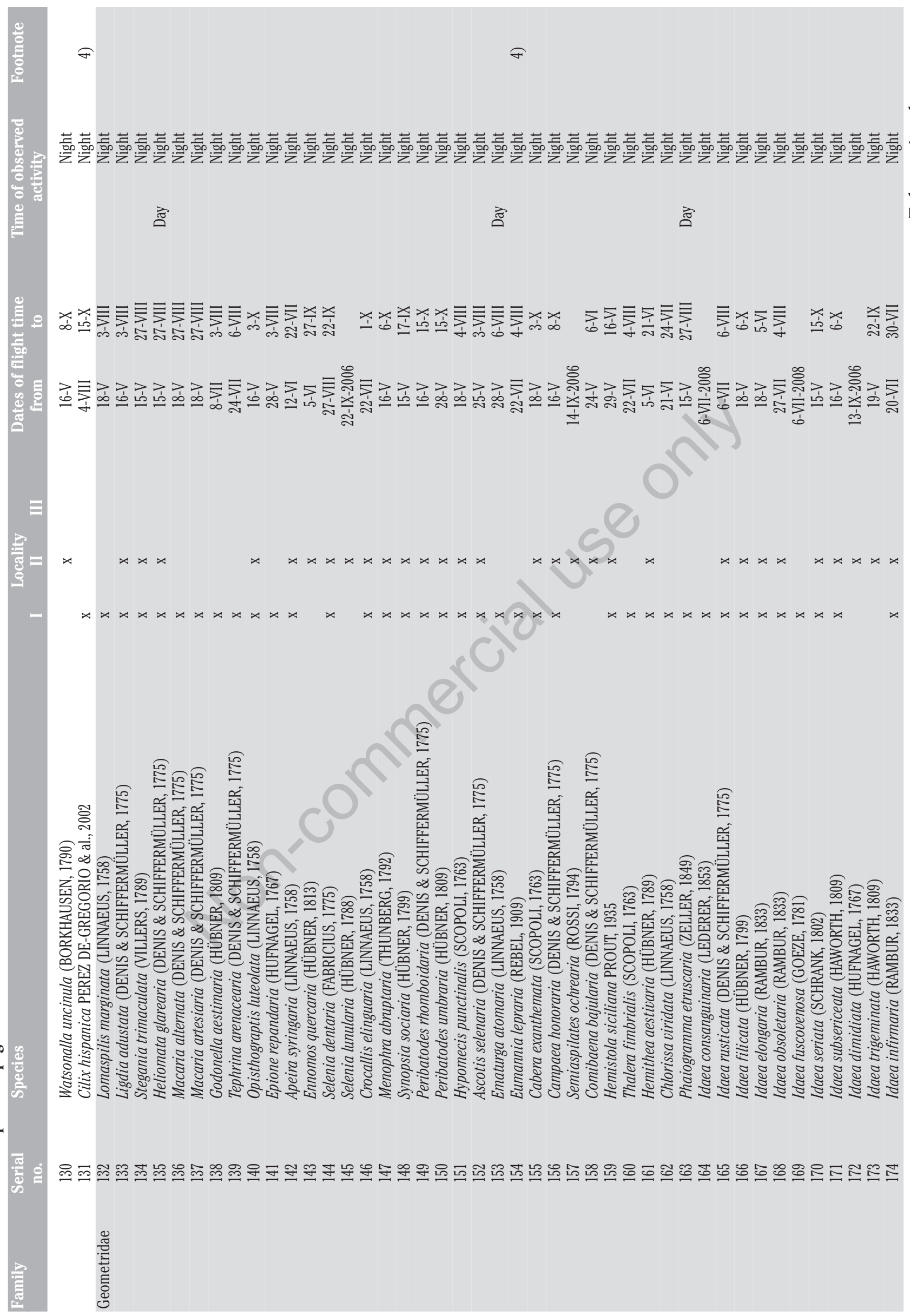




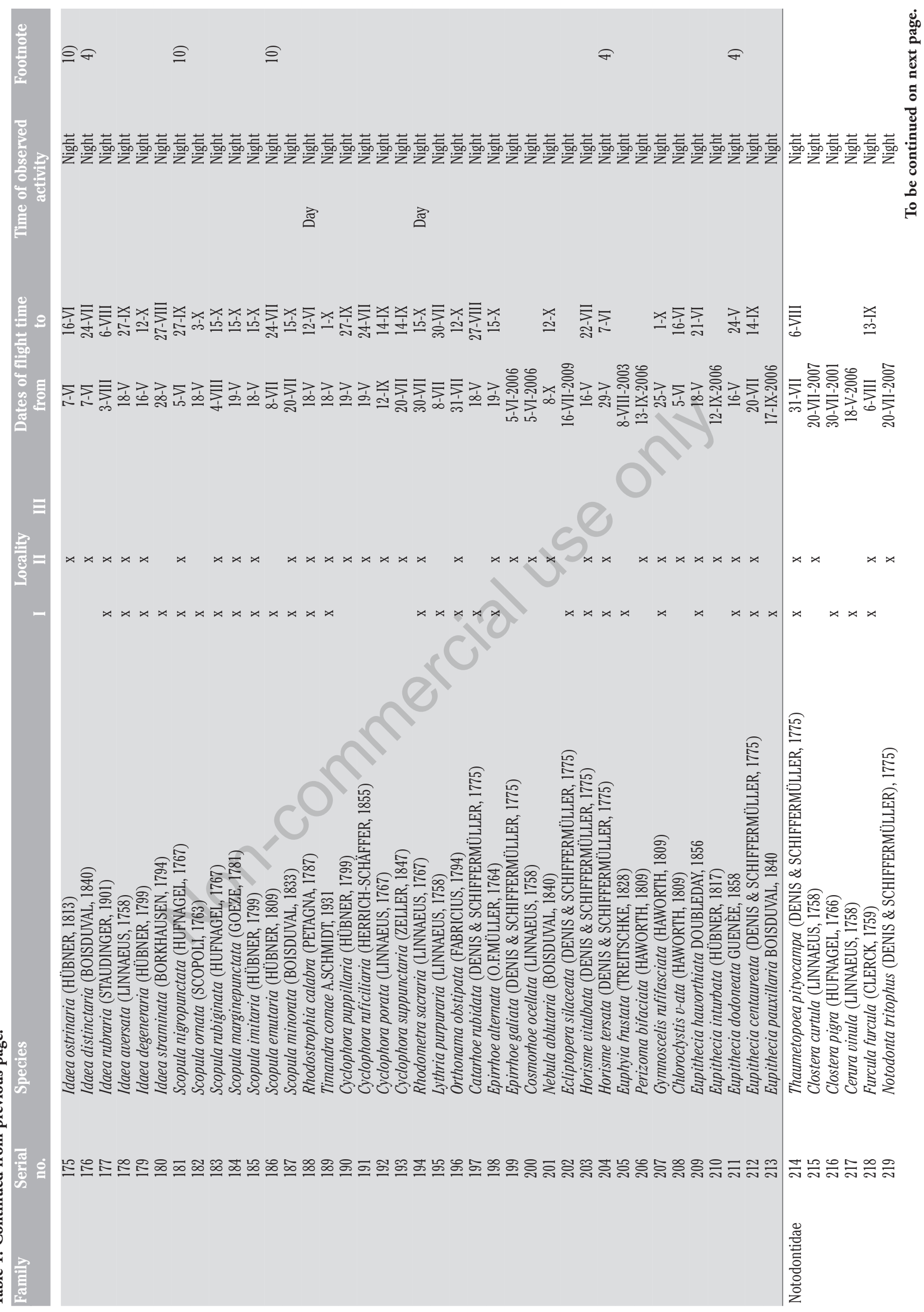

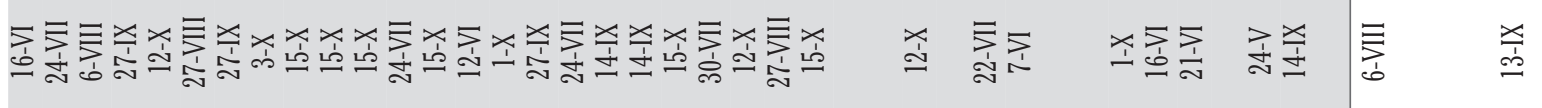

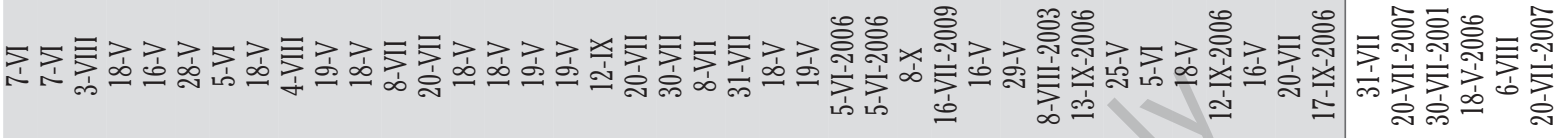




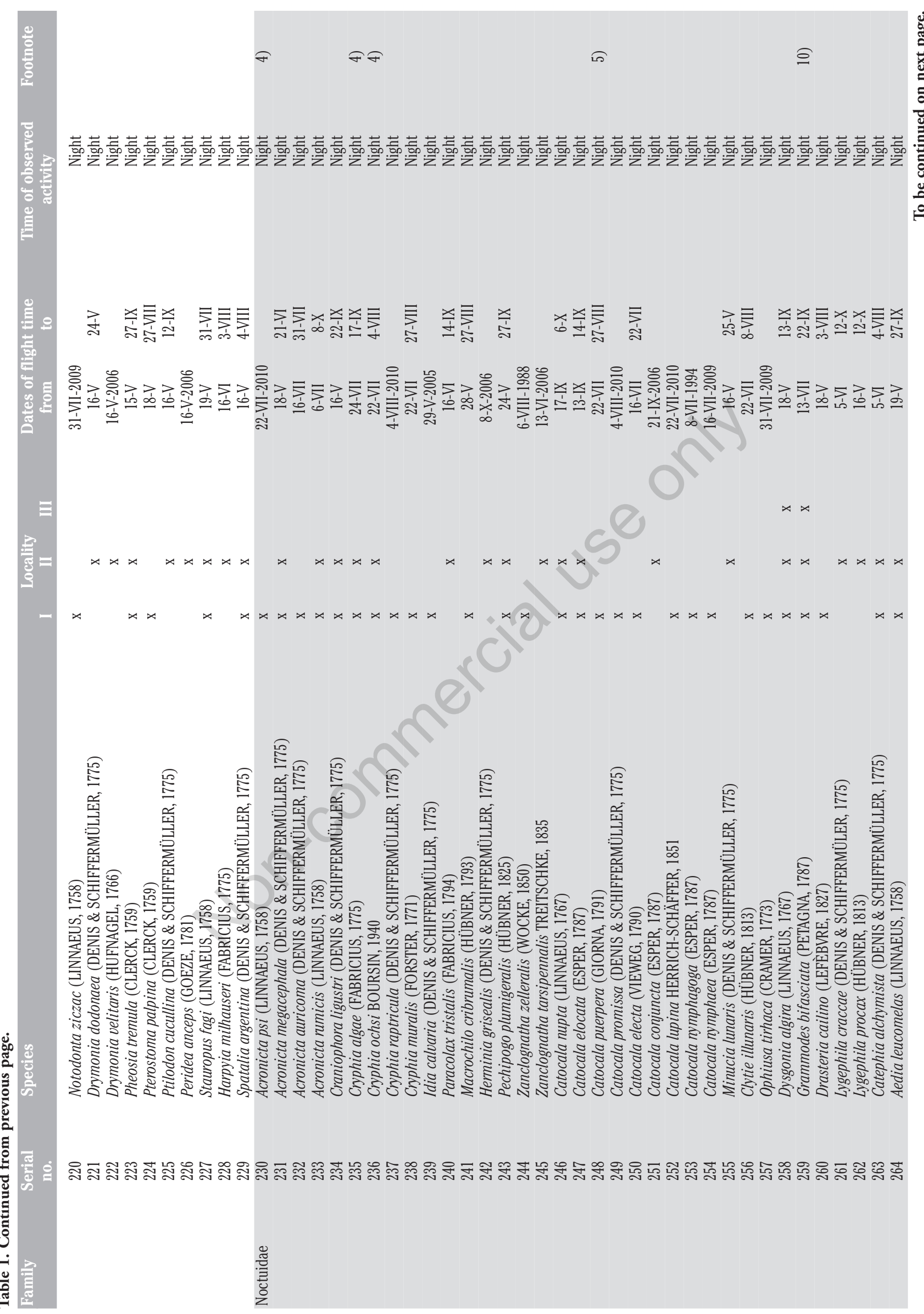




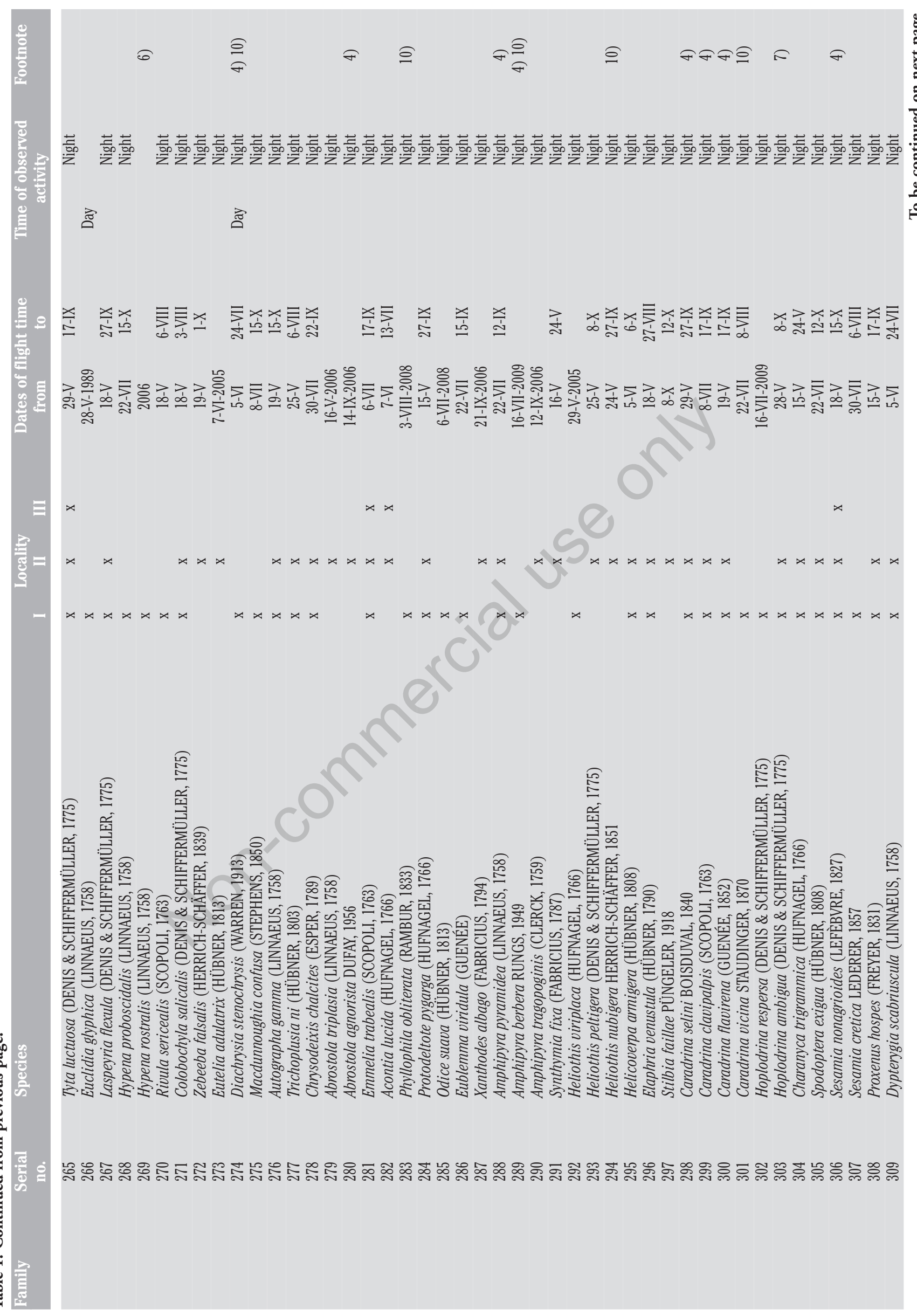




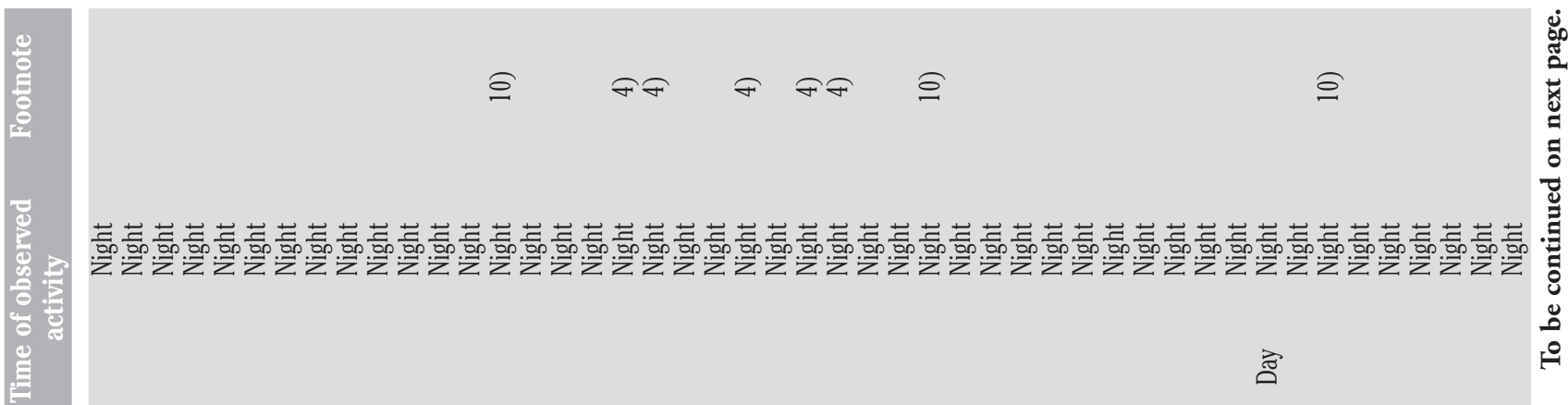

严。

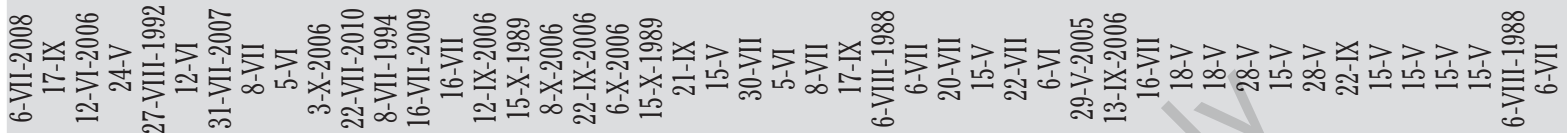

$\equiv$

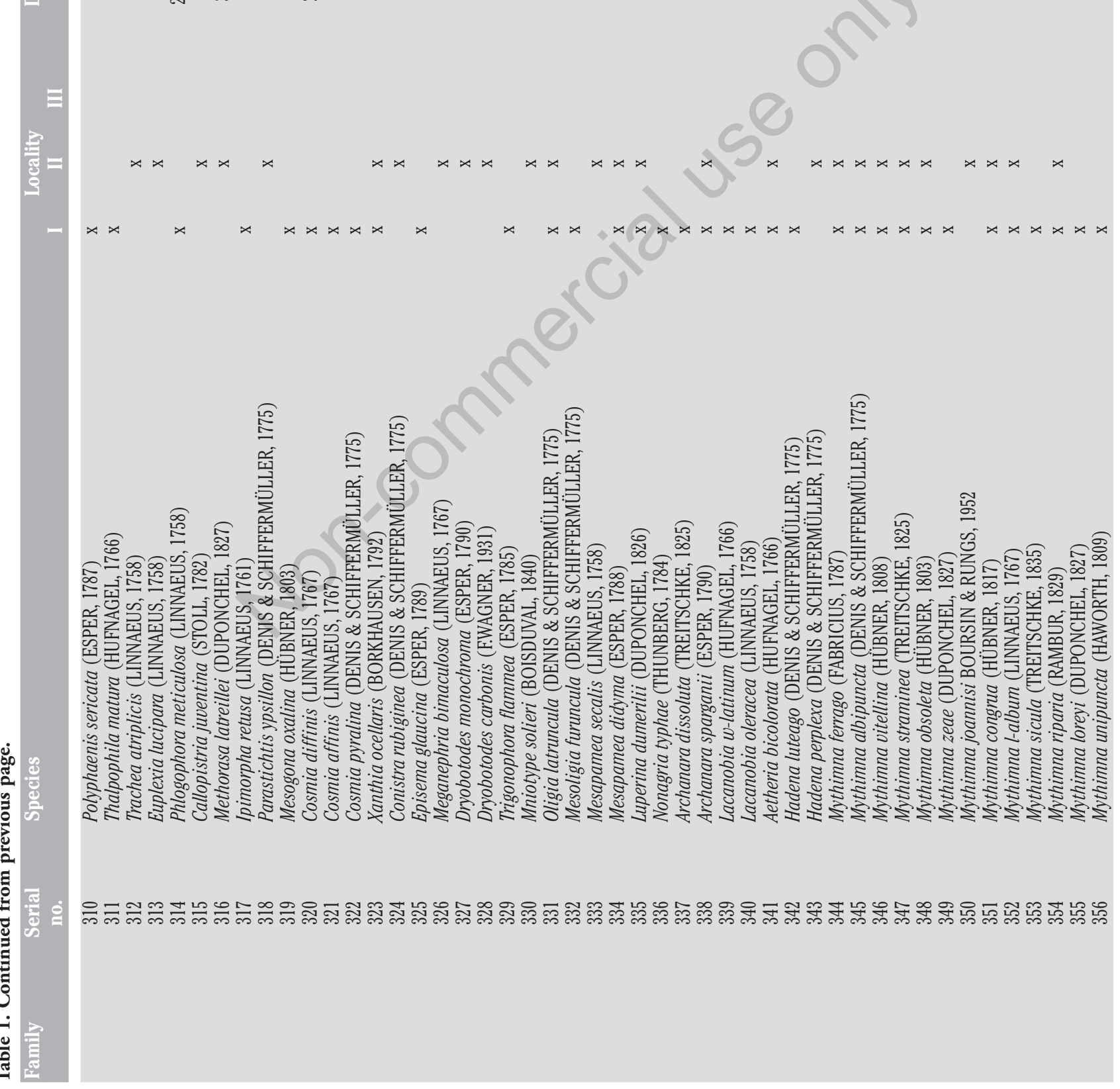




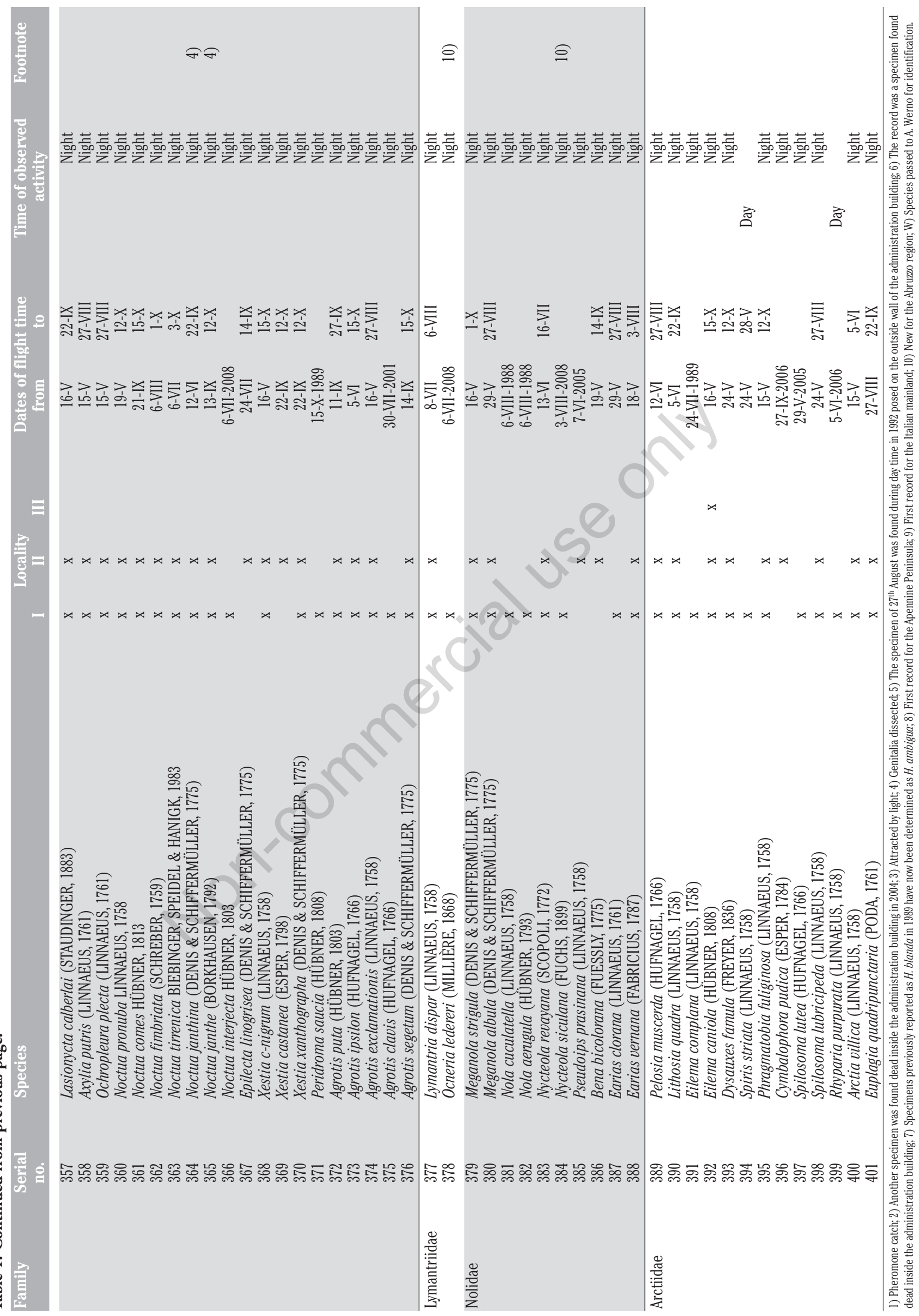




\section{The investigation area}

The lower Sangro valley is located in the Chieti Province of Abruzzo in Central Italy (Figure 1). It consists of a $20 \mathrm{~km}$ long by $2.5 \mathrm{~km}$ wide plain, stretching between the estuary of the river Aventino into the river Sangro and the estuary of the river Sangro into the Adriatic Sea. Today, the area is mainly used for agriculture. Extensive industrial and commercial areas have also been developed. Housing developments are only located along the perimeter. Natural areas are only to be found in the immediate vicinity of the river and in the two nature reserves.

The Oasi di Serranella has been described by Zahm (1989) (Figure 2). It is an area of 180 ha where the estuary of Aventino river enters the Sangro river. Approximately 90 ha of water surface are dammed up to 90 $m$ above sea level. The protected area essentially consists of extensive wetlands, within which a number of microhabitats with their respective vegetation can be distinguished. Potamogeton species are typically present in the areas of flowing water. Phragmites communis and several Typha species grow in large stands of reeds. Two wide strips of floodplain forests continue along the perimeter of the marshland with Alnus glutinosa, a number of Salix and Populus species, as well as Quercus robur in the drier areas. Mediterranean plants grow on a xeric plateau e.g. Spartium junceum, Helichrysum italicum and Cistus incanus.

The Lecceta di Torino di Sangro has been described by Di Fabrizio (2004) (Figure 3). The 170 ha of the natural reserve extend from the banks of the Sangro river near its estuary up and across the slopes of the costal hills (2-60 m above sea level) and down the slopes facing the coast. It is one of the last remains of the original Adriatic coast forests. Although called Lecceta (forest of Quercus ilex) it is actually a mixed deciduous forest with a dominating number of Quercus ilex. Co-occurring species

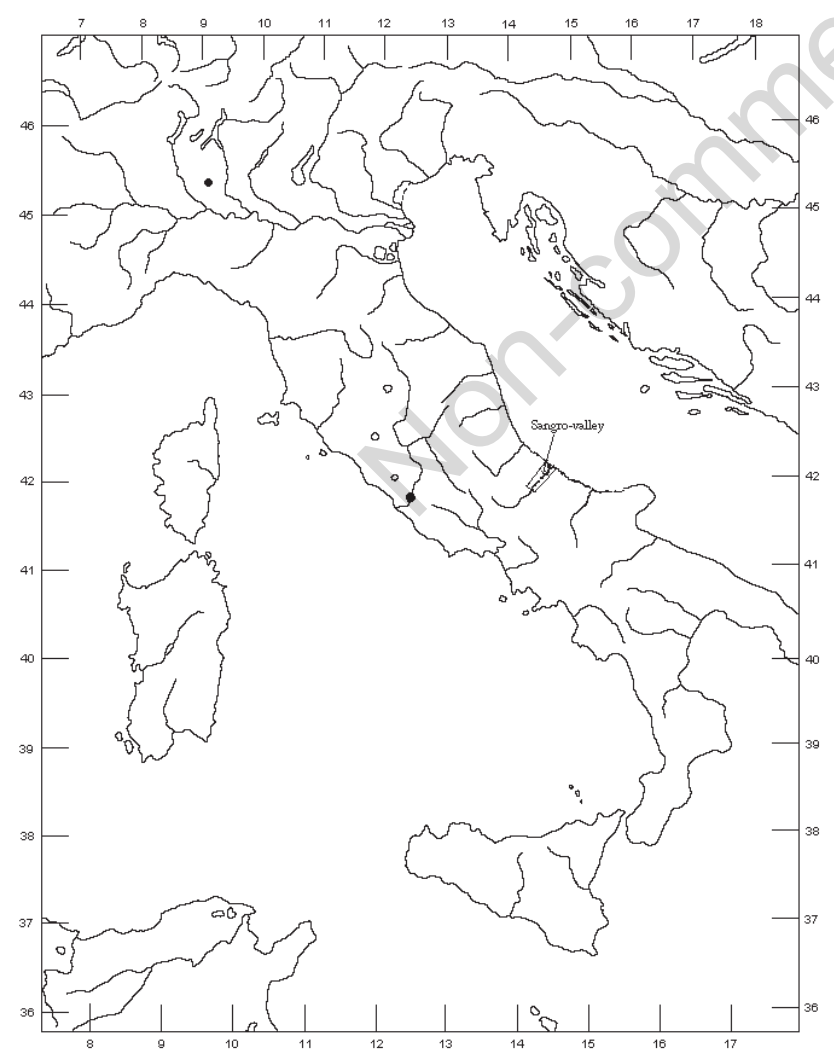

Figure 1. Geographical map of Italy with indication of the lower Sangro valley. include Quercus pubescens, Q. cerris, Carpinus orientalis, Coronilla emerus, Acer neapolitanum, Crataegus monogyna and Ligustrum vulgare. The undergrowth is for the most part very dense, almost impenetrable. Hedera helix, Smilax aspera and Ruscus aculeatus are well represented in the forest and brushwood area. Coastal steppes and Mediterranean Macchia spread in open areas with Cistus creticus and Pistacia lentiscus. Typical riverbank tree species, e.g. Salix and Populus species, grow along the river Sangro.

\section{Results}

The first results of the Oasi di Serranella (1988-1989) were published in 1989. They have been integrated in this final study in order to provide a comprehensive overview. It is unknown to the author whether other entomologists have made any recordings or published any reports on the area of investigation and, therefore, no additional data have been included.

A total of 1878 single observations were recorded over many years of investigation. The study recorded 401 species, 15 of which were first recorded for the Abruzzo region, one was new for the Italian mainland and one for the Apennine peninsula. Table 2 shows the distribution of records and species of each of the three groups Microlepidoptera, Rhopalocera and Macroheterocera.

The investigation of the individual areas resulted in the following number of species: Oasi di Serranella 287, Lecceta di Torino di Sangro 253, Coastal area 12.

The individual recorded species are shown in Table 1. Localities, observed flight times and observed times of activity are reported as well as the associated families.

\section{Presentation of results}

Systematics and nomenclature follow Karsholt \& Razowski (1996) and with regards to Geometridae (Hausmann, 2001, 2004; Mironov, 2003) as published so far. Results from three localities are presented: I Oasi di Serranella; II Lecceta di Torino di Sangro; III coastal area of the Sangro valley (Table 1). Only the earliest and latest observations are shown. No year is given since these periods of flight are independent of year of observation. One-off observations are also listed.

For reasons of clarity, author names and publication years are not presented in the text. The following 17 species are also shown in the Appendix.

Phtheochroa ingridae (Figures A1 and A5) was only recognized as an independent species and distinguished from $P$. rugosana in 1990 by Huemer. The species is endemic for Italy. The holotype come from the Kalterer See (Trentino-Alto Adige region), the paratypes come from the same region and from the Veneto region. Trematerra (2003) only mentions these two regions as distribution area. The 3 females from the Lecceta di Torino di Sangro match the description and figures of these types in terms of habitus as well as genitalia. Therefore, their discov-

Table 2. Average number of records per species in each of the groups.

\begin{tabular}{lccc} 
Groups & Records & Species & Average \\
Microlepidoptera & 89 & 63 & 1.41 \\
Rhopalocera & 100 & 44 & 2.27 \\
\hline Macroheterocera & 1689 & 294 & 5.74 \\
Total & 1878 & 401 & 4.68 \\
\hline
\end{tabular}


ery on $7^{\text {th }}$ May 2006 has been the first and only record of the species on the Apennine Peninsula to date.

Within Italy, Herculia fulvocilialis (Figure A2) has only been mentioned in Sicily by Bassi et al. (1995), Speidel (1996) and by Slamka (2006). Therefore, the species can be considered new for the Italian mainland.

Gegenes nostrodamus (Figures A4, A6) is very similar to $G$. pumilio. Length of forewings and underside of wings, in particular of hindwings, provide enough evidence for a clear determination of the collected specimen. According to Parenzan and Porcelli (2005-2006), the species is also present in all remaining regions of the peninsula.

Idaea ostrinaria (Figure A3), a pretty thermophilic Sterrhinae, was also found by the author on the southeast slope of the Majella mountain, in the Orfento valley, and on the Gran Sasso mountain. This species was also mentioned by Parenzan and Porcelli (2005-2006) for all remaining regions of the peninsula.

Scopula nigropunctata (Figure A3) appears to be more common and more widely distributed in the Abruzzo region than was previously thought considering the fact that to date it has not been mentioned in literature for this region. It has also been found by the author at sever-

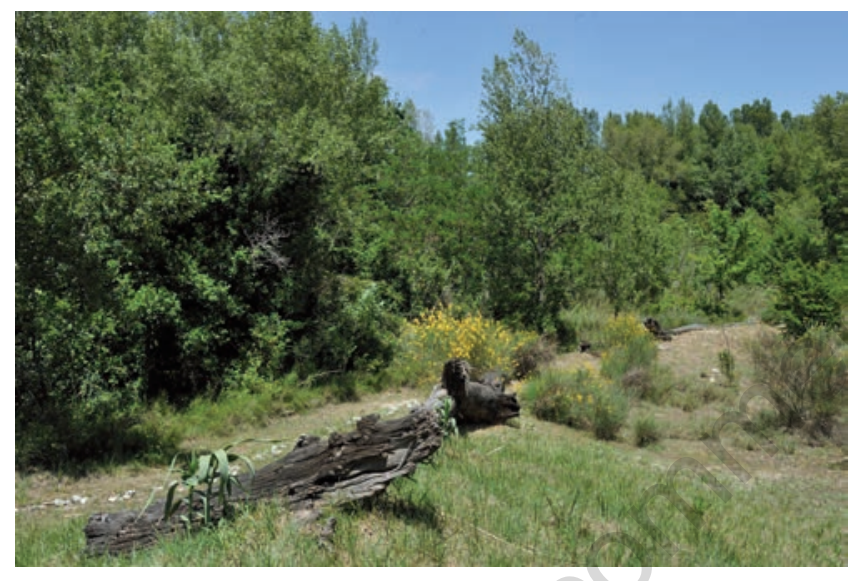

Figure 2. Detail of Riserva Naturale Oasi di Serranella (photo M. Pellegrini).

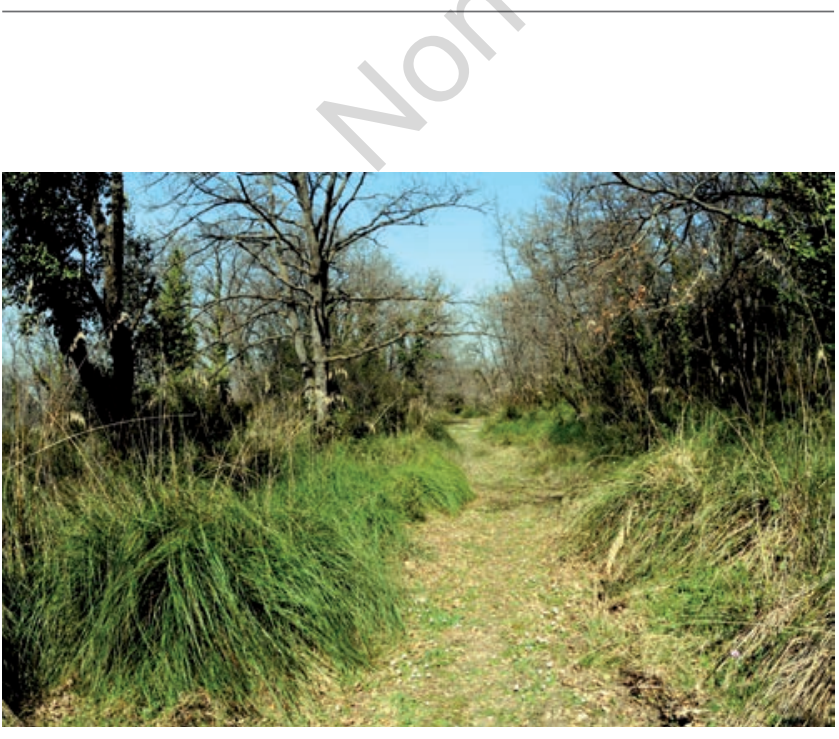

Figure 3. Detail of Riserva Naturale Lecceta di Torino di Sangro (photo M. Pellegrini). al locations on the Majella mountain and in Francavilla, and by Dell'Agata (Grassi et al., 2003-2005, unpublished data) on the Gran Sasso mountain.

Scopula emutaria (Figure A3) has also been found in Francavilla together with $S$. nigropunctata.

Grammodes bifasciata (Figure A3) is a tropical and subtropical species whose distribution area also includes southern Europe.

Diachrysia stenochrysis (syn. tutti) (Figures A3 and A7) and D. chrysitis often show similarities in forewing drawing, as well as in the genital structure in males, so that a clear determination is not always possible. However, in the case of the 2 available examples the features were unambiguous.

Apart from the single find of Phyllophila obliterata (Figure A3) the author could not obtain any further recordings in the Abruzzo region.

Recordings of Amphipyra berbera, Heliothis nubigera, Caradrina vicina and Nycteola siculana (Figure A3, A. berbera also Figure A8) have also been made for the Majella mountain. The latter has also been located on the Gran Sasso mountain by Grassi et al. (2003-2005, unpublished data). Nomenclature of $C$. vicina differs from Nowacki \& Fibiger (1996) who used the genus Eremodrina that has subsequently been down-graded to subgenus level by Hacker (2004).

Xanthia ocellaris (Figure A3), a very variable species, is one of the less frequent autumn species of the genus Xanthia. Apart from the 2 examples from the investigation area, the author could not obtain any further recordings from the Abruzzo region.

Archanara dissoluta (Figure A3) lives in wet habitats with stands of reeds where its caterpillars develop in the stems of Phragmites species. The author obtained one further recording for the Abruzzo region on the lower slopes of the Majella mountain on the banks of the river Aventino near Pianimarini.

Mythimna joannisi (Figure A3) is a species of Pan-African distribution that is also found on the major western Mediterranean islands, reaching continental Europe on the southern and eastern coast of Iberia and in southern Italy. While it was discovered in Lazio on the Tyrrhenian side of the Apennine Peninsula, the species has not previously been detected on the Adriatic side beyond Apulia. Its habitat is the reed areas near the coast where its feeding plant Phragmites species grows.

Ocneria ledereri (Figure A3) appears to be a rare species in the Abruzzo region. Apart from this single specimen, the author could not obtain any further recordings.

\section{Conclusions}

This study contributes valuable information to widen our knowledge of the occurrence and distribution of the Lepidoptera of central Italy. Fifteen species are published for the Abruzzo region for the first time; 2 species are new for the Italian peninsula.

\section{References}

BASSI G., PASSERIN D’ENTRÈVES P., SPEIDEL W., ZANGHERI S., 1995 Lepidoptera Pyraloidea. - In: Minelli A., Ruffo S., La Posta S. Checklist delle specie della fauna italiana. Band 87 - Calderini, Bologna.

DI FABRIZIO F., 2004 - Aree protette d'Abruzzo. - Cogecstre, Penne.

FIBIGER M., (ed.), 1990 - 2010 - Noctuidae Europaeae, vol. 1-12. Entomological Press, Soro.

HACKER H., 2004 - Revision of the Genus Caradrina OCHSENHEIMER, 1816, with notes on other genera of the tribus Caradrina (Lepidoptera, Noctuidae). - Esperiana 10. Pemberley Natural History Books BA, IVER, Bucks. 
HAUSMANN A., 2001 - Introduction, Archiearinae, Orthostixinae, Desmobathrinae, Alsophilinae, Geometrinae. - In: Hausmann A., (ed.). The geometrid moths of Europe, vol. 1. - Apollo Books, Stenstrup: 1-282.

HAUSMANN A., 2004 - Sterrhinae - In: Hausmann A., (ed.). The geometrid moths of Europe, vol. 2. - Apollo Books, Stenstrup: 1-600.

HUEMER P., 1990 - Eine neue Phtheochroa-Art aus Norditalien (Lepidoptera: Tortricidae). - Nachr. Bl. Bayer. Ent. 39: 82-87.

KARSHOLT 0., RAZOWSKI J., (eds.) 1996 - The Lepidoptera of Europe. A Distributional Checklist. - Apollo Books, Stenstrup.

MIRONOV V., 2003 - Larentiinae II (Perizomini and Eupitheciini) - In: Hausmann A., (ed.). The geometrid moths of Europe, vol. 4. - Apollo Books, Stenstrup: 1-463.

NOWACKI J., FIBIGER M., 1996 - Noctuidae. - In: Karsholt O., Razowski J., (eds.). The Lepidoptera of Europe. - Apollo Books, Stenstrup: 251-293.

PARENZAN P., PORCELLI F., 2005-2006 - I Macrolepidotteri Italiane, Fauna Lepidopterorum Italiae (Macrolepidoptera). - Phytophaga XV: 5-393.

PARENZAN P., PORCELLI F., 2006-2007 - I Macrolepidotteri Italiane, Fauna Lepidopterorum Italiae (Macrolepidoptera). - Addenda et corrigenda I. - Entomologica 40: 153-221.

PROLA C., PROVERA P., RACHELI T., SBORDONI V. 1978a - I Macrolepidotteri dell'Appennino Centrale. Parte I. - Fragm. Entomol. 14: 1-217.
PROLA C., PROVERA P., RACHELI T., SBORDONI V. 1978b - I Macrolepidotteri dell'Appennino Centrale. Parte II. - Boll. Ass. Romana Entomol. 32: 1-238.

PROLA C., RACHELI T., 1979 - I Geometridi dell'Italia Centrale. Parte I, Oenochrominae, Hemitheinae, Sterrhinae, Larentiinae (Pars). Boll. Ist. Entomol. Univ. Bologna 34: 191-246.

PROLA C., RACHELI T., 1980 - I Geometridi dell'Italia Centrale. Parte II, Larentiinae. - Boll. Ist. Entomol. Univ. Bologna 35: 29-108.

SCIARRETTA A., ZAHM N., 2002 - I Macrolepidotteri dell' 'Abetina di Rosello' (Abruzzo) con note faunistiche, biogeografiche ed ecologiche. - Phytophaga XII: 25-42.

SLAMKA F., 2006 - Pyraloidea Europas, Band I. - Bratislava (Slowakei). SPEIDEL W. 1996. - Pyralidae - In: Karshholt O., Razowski J. (eds.), The Lepidoptera of Europe. - Apollo Books, Stenstrup: 166-196.

TEOBALDELLI A., 1976 - I Macrolepidotteri del Maceratese e dei Monti Sibillini (Appennino Umbro-Marchigiano). - Note App. Sperim. Entomol. Agr. 16: 81-346.

TREMATERRA P., 2003 - Catalogo dei Lepidoptera Tortricidae della fauna italiana: geonemia, distribuzione in Italia, note biologiche, identificazione. - Boll. Zool. Agr. Bachic. Ser. II 35(Supp 1): 3-270.

WEIGT H.J., 2009 - Eupithecia, Monografie der Blütenspanner Mitteleuropas. - PDF-Manuskript Hans-Joachim Weigt.

ZAHM N., 1989 - Lepidopteren aus der Oasi di Serranella (Mittelitalien, Abruzzen) (Lepidoptera). - Boll. Ass. Romana Entomol. 43: 1-9. 


\section{Contribution to the knowledge of the Lepidoptera Fauna of the lower Sangro valley in the Abruzzo region of Central Italy}

\section{Appendix}

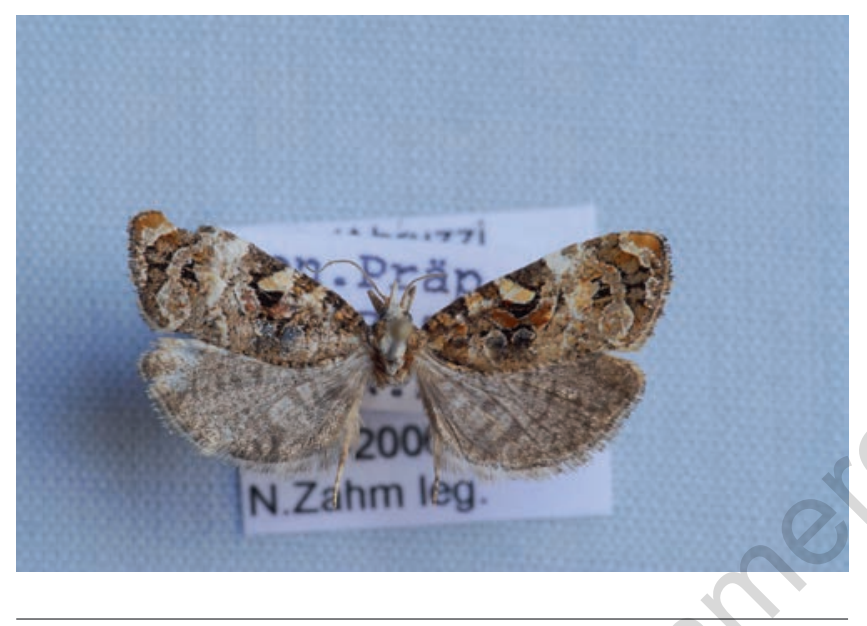

Figure A1. Phtheochroa ingridae (photo Hinsberger).

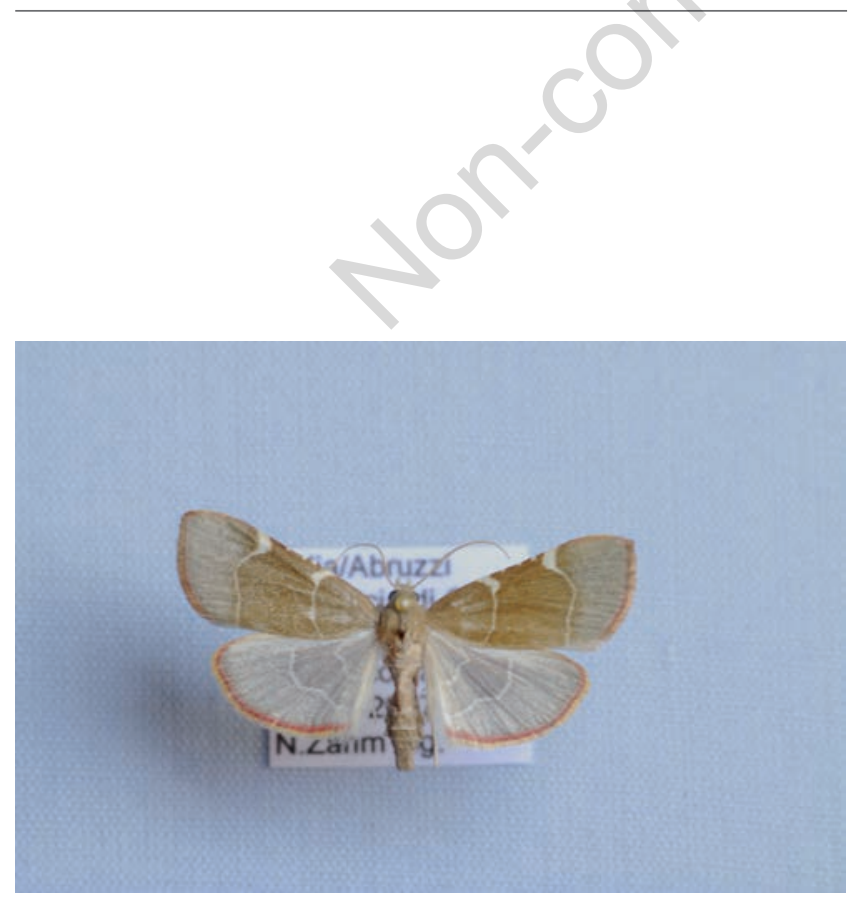

Figure A2. Herculia fulvocilialis (photo Hinsberger).

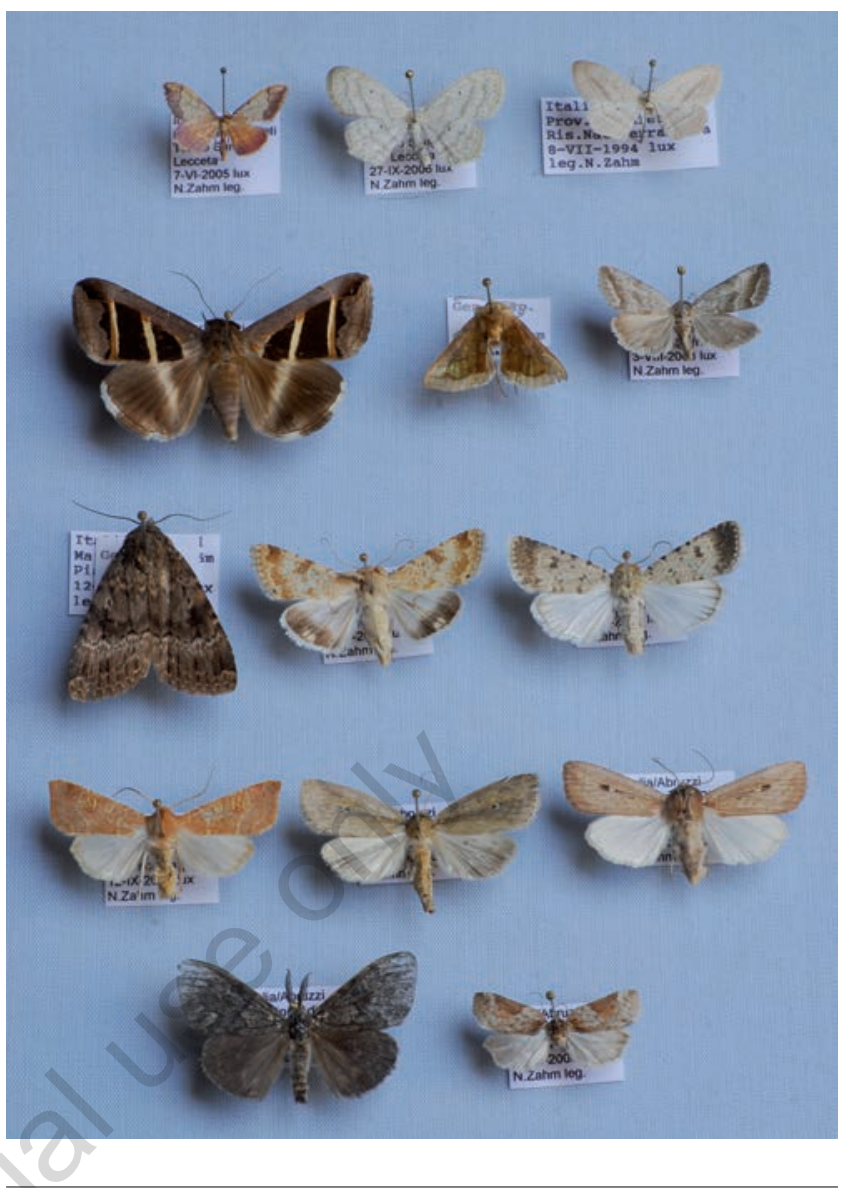

Figure A3. $1^{\text {st }}$ row from left: Idaea ostrinaria, Scopula nigropunctata, Scopula emutaria. $2^{\text {nd }}$ row from left: Grammodes bifasciata, Diachrysia stenochrysis, Phyllophila obliterata. $3^{\text {rd }}$ row from left: Amphipyra berbera, Heliothis nubigera, Caradrina vicina. $4^{\text {th }}$ row from left: Xanthia ocellaris, Archanara dissoluta, Mythimna joannisi. $5^{\text {th }}$ row from left: Ocneria ledereri, Nycteola siculana (photo Hinsberger).

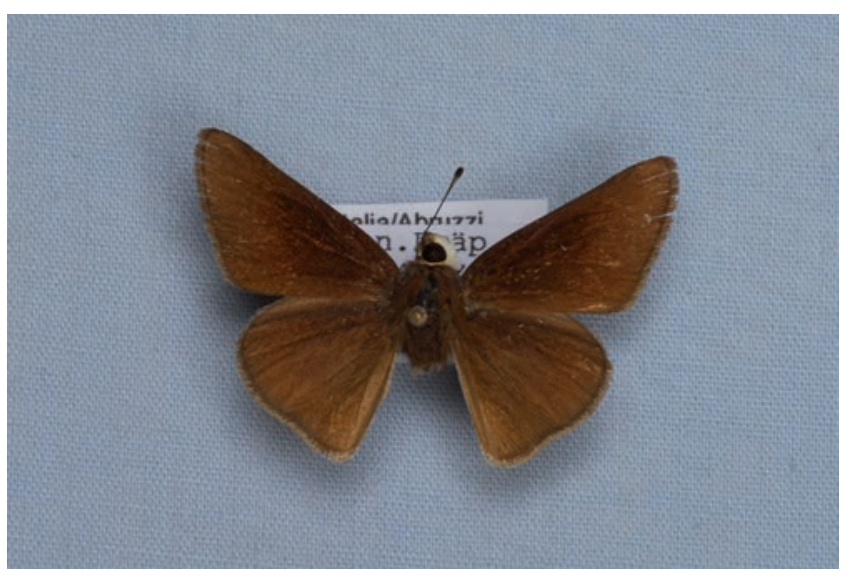

Figure A4. Gegenes nostrodamus (photo Hinsberger). 


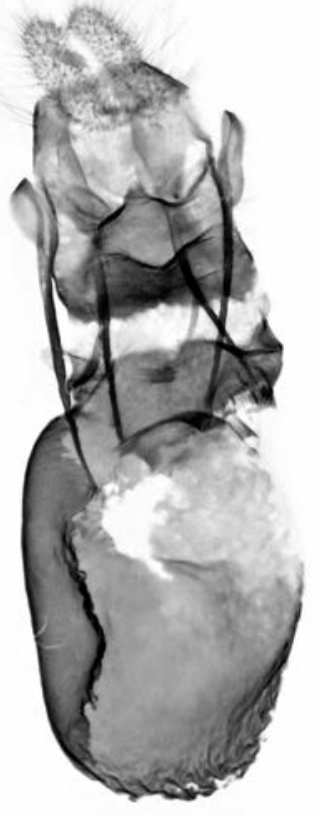

Figure A5. Phtheochroa ingridae female genitalia (photo Müller).
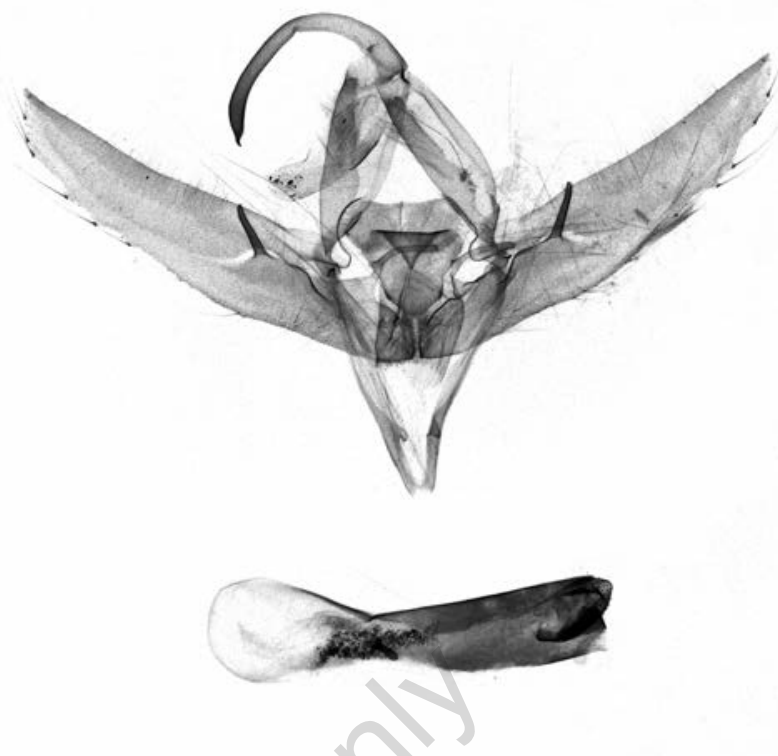

Figure A7. Diachrysia stenochrysis male genitalia (photo Müller).

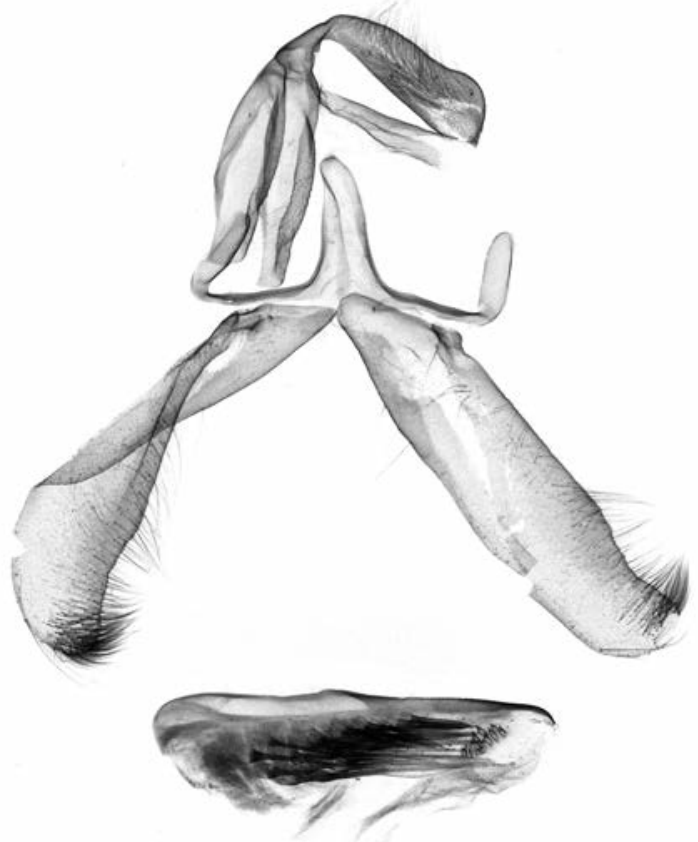

Figure A6. Gegenes nostrodamus male genitalia (photo Müller).

Figure A8. Amphipyra berbera male genitalia (photo Müller). 